\title{
Mucin Reactivity after Acute Exposure to Mercury and Zinc Chloride in Neurocytes of Freshwater Snail Bellamya bengalensis: A Histochemical Study
}

\author{
Sunil Londhe ${ }^{1}$ and Nitin Kamble ${ }^{2}$ \\ ${ }^{1}$ Shri Shiv Shahu College, Sarud, Kolhapur 416 214, India \\ ${ }^{2}$ Department of Zoology, Shivaji University, Kolhapur 416 004, India \\ Correspondence should be addressed to Sunil Londhe; sunil_londhe84@rediffmail.com
}

Received 30 June 2014; Revised 19 September 2014; Accepted 19 September 2014; Published 2 October 2014

Academic Editor: Jesus Simal-Gandara

Copyright (C) 2014 S. Londhe and N. Kamble. This is an open access article distributed under the Creative Commons Attribution License, which permits unrestricted use, distribution, and reproduction in any medium, provided the original work is properly cited.

Central nervous system (CNS) of gastropods is extensively studied for its pathology and immunocytology; there is scanty information on histochemical alterations in neuronal cells due to heavy metal. This study was designed to investigate histochemical alterations in cerebral neurons of freshwater snail Bellamya bengalensis after intoxication with mercuric chloride $\left(\mathrm{HgCl}_{2}\right)$ and zinc chloride $\left(\mathrm{ZnCl}_{2}\right)$. As per chemical components cerebral ganglia of Bellamya bengalensis showed three different zones, namely, periganglionic connective tissue sheath, interperikaryonal space, and neuropil. After intoxication, increased acidic content in extracellular matrix (ECM) of neuronal cells was found. These alterations were directly proportional to time of exposure period. From results, $\mathrm{HgCl}_{2}$ proved its highly toxic nature over chemical composition of cerebral neuronal cells of freshwater snail Bellamya bengalensis compared to $\mathrm{ZnCl}_{2}$ intoxication.

\section{Introduction}

A wide range of inorganic and organic compounds caused aquatic contamination including heavy metals, combustible and putrescible substance, hazardous wastes, explosives, petroleum products, and phenol and textile dyes [1]. The major component of inorganic contaminants has some different problems than organic contaminants $[2,3]$. Notably aquatic ecosystems are often polluted with anomalously high levels of toxicants (organic and inorganic substances), which find their way into the aquatic systems with waste and effluents generated from industrial enterprises [4]. Heavy metals are highly active contaminants of biotic material, which enters the aquatic environment through a number of routes [5]. Aquatic poisoning by metals has increased during last decades due to their extensive use in agricultural, chemical, and industrial processes resulting in threat to living organisms [6]. As a result, inorganic contamination has increased level of transfer across food chain/web leading to health hazards [7]. Heavy metal pollution of terrestrial and aquatic ecosystems has long been recognized as a serious environmental concern [8].

From the invertebrates, aquatic and terrestrial molluscs are measurably affected by heavy metal pollution. Heavy metal continued to be common pollutant in aquatic ecosystem and proved toxic to aquatic organism $[9,10]$. Bivalve and gastropod molluscs are excellent sentinel organisms for the study of toxic effects of metals in aquatic ecosystems [11]. Maximum concentration of heavy metal in aquatic or terrestrial media affects numerous phenomena involved in the development and maintenance of molluscan physiology as feeding, growth, reproduction, and maturity of animal [12]. Some findings show that snails in polluted areas have high levels of cadmium in the digestive glands, kidney, gills, and muscle [13] as well as in the foot [14] and shell [15]. Reference [16] reported that cadmium poisoning altered normal histology of gills by bioaccumulating it in the proboscis, 
esophagus, stomach, rectum, and gills of edible snail Babylonia areolata. Reference [17] observed the bioaccumulation and histopathological effects in hepatopancreas, ovotestis from giant land snail Archachatina marginata. Gastropod molluscs are suitable for studying neuronal mechanism, which integrates different motor systems into coordinated behavior. Comprehensive knowledge has been accumulated in the past decades on the organization and development of prominent and extensive study in many objectives for analyzing simple neuronal network related to behavior of an organism [18].

Available literature seems to be scanty information about impact of heavy metal on histochemical alteration in the cerebral neuronal cells of freshwater molluscs. The present study is designed to investigate the alteration in histochemical components from cerebral neuronal cells of freshwater snail Bellamya bengalensis.

\section{Material and Method}

2.1. Experimental Animals. Adult snails Bellamya bengalensis $(4-5 \mathrm{~cm} \mathrm{~L}, 2-3 \mathrm{~cm} \mathrm{~W}$, and $3-4 \mathrm{~g} \mathrm{Wt})$ were collected from Rajaram tank, nearby National Highway $(\mathrm{NH}) 04(0.5 \mathrm{~km})$, situated in the campus of Shivaji University, Kolhapur, Maharashtra, India, at latitude and longitude of $16^{\circ}, 40^{\prime} 47.49^{\prime \prime}$ $\mathrm{N}$ and $76^{\circ}, 16^{\prime} 01.86^{\prime \prime} \mathrm{E}$. Animals were carried by plastic container to the laboratory. The snails were cleaned for removal of algal mass and mud. Well-cleaned animals were transferred to plastic trough $(60 \mathrm{~cm} \times 30 \mathrm{~cm}), 50$ animals in each. All the snails were acclimatized at room temperature by providing fresh air in the water prior to the experiments.

2.2. Toxicant and Animal Toxicity. A water miscible powder form of mercuric chloride $\left(\mathrm{HgCl}_{2}\right)$ and zinc chloride $\left(\mathrm{ZnCl}_{2}\right)$ (Himedia Laboratory Pvt. Ltd.) was procured from Fumes Chemicals, Kolhapur, and used for the toxicity assessment. Mortality and $\mathrm{LC}_{50}$ at $24 \mathrm{~h}, 48 \mathrm{~h}, 72 \mathrm{~h}$, and $96 \mathrm{~h}$ exposure were calculated using the Probit analysis method (Finney, 1971). All experiments were repeated three times for the calculation of mean $\mathrm{LC}_{50}$.

2.3. Tissue Preparation. After completion of each exposure period animals were sacrificed to dissect out cerebral ganglia. Dissected ganglions were fixed in $10 \%$ formalin, washed in $70 \%$ ethanol up to $72 \mathrm{~h}$, dehydrated in alcoholic grades (90\% and $100 \%)$, then cleared in xylene, and embedded in Paraplast. The prepared tissue blocks were sectioned through rotary microtome at $6 \mu \mathrm{m}$ thickness and applied for histochemistry.

\subsection{Histochemistry}

\subsubsection{Neutral Mucosubstances}

(i) Periodic Acid Schiff (PAS) Technique [19]. As an oxidizing agent, $1 \%$ of periodic acid in PAS reaction was used as oxidizing agent for $5 \mathrm{~min}$. Sections were washed with distilled water and treated with $1 \%$ of Schiff's reagent for $20 \mathrm{~min}$. Sections were rinsed for three times (up to $6 \mathrm{~min}$ ) with $0.5 \%$ of sodium metabisulphite, washed with distilled water, dehydrated through a series of increasing orders of alcoholic grades, cleared in xylene, and mounted in DPX.

\subsubsection{Acidic Mucosubstances}

(i) Alcian Blue $(A B)$ at $p H 1.0$ [20]. Hydrated sections were brought to distilled water and stained for $30 \mathrm{~min}$ in $1 \%$ of $\mathrm{AB}$ in $0.1 \mathrm{~N} \mathrm{HCl}(\mathrm{pH} 1.0)$. Sections were blotted on filter paper, dehydrated, cleared in xylene, and mounted in DPX. Only sulphomucins were found intense blue.

(ii) Alcian Blue (AB) at pH 2.5 [20]. After hydration, sections were brought to distilled water, rinsed in $3 \%$ acetic acid, stained by $1 \%$ of $\mathrm{AB}$ in $3 \%$ of acetic acid at $\mathrm{pH} 2.5$ for $30 \mathrm{~min}$, washed with distilled water, dehydrated, cleared in xylene, and mounted in DPX. Weakly acidic mucosubstances as hyaluronic acid and sialomucins were found stained dark blue.

2.4.3. Chapman's Mercury Bromophenol Blue Technique for Proteins [21]. After deparaffinization, sections were hydrated by passing through absolute $90 \%, 70 \%, 50 \%$, and $30 \%$ alcohol and then to distilled water for $5 \mathrm{~min}$, stained in $1 \% \mathrm{HgCl}_{2}$, $0.05 \%$ sodium bromophenol blue, and $2 \%$ aqueous acetic acid for $10 \mathrm{~min}$, transferred to $0.5 \%$ acetic acid for $10 \mathrm{~min}$, transferred to tertiary butyl alcohol (2 changes) for $30 \mathrm{~min}$ until the sections turned blue, and then transferred to $0.5 \mathrm{~mL}$ n-butylamine (in $100 \mathrm{~mL}$ xylene) until sections turned blue completely. Sections were cleared in xylene and mounted in DPX. Protein content was stained intensely blue.

2.4.4. Sudan Black B Technique for Lipids [22]. After hydration, the sections were brought to distilled water, then treated with $1 \%$ potassium dichromate for $1 \mathrm{hr}$, making lipid resistant to inorganic solvent by oxidizing phospholipids, washed with distilled water, stained with Sudan Black B for $30 \mathrm{~min}$, differentiated with $70 \%$ alcohol, after staining, cleared in xylene, and mounted in DPX. The lipid contained stained deep blue. Brownish black colour may be even an indication of lipids content.

2.4.5. Microscopic Observation. Measurement of staining intensity from different zones of CNS was carried out by visual observation in five tissues of each experimental group. The staining intensity scoring in control and excremental group was noted as follows: +++, strong intensity; ++, moderate intensity; + , pale/light intensity.

\section{Results}

In the cerebral ganglia of experimental animals, extracellular matrix (ECM) occurred in three different anatomical ganglionic units as follows. (i) Periganglionic connective tissue sheath (PS) includes the membrane lamina, muscle fibers, axon, and glial processes. (ii) Interperikaryonal space (IS) includes the perineuronal net. (iii) Neuropil (N) contained glial elements, with the mass of axon projection (Figure 1). The quantitative differentiation in ECM zones of CNS in Bellamya bengalensis was shown in Table 1. 


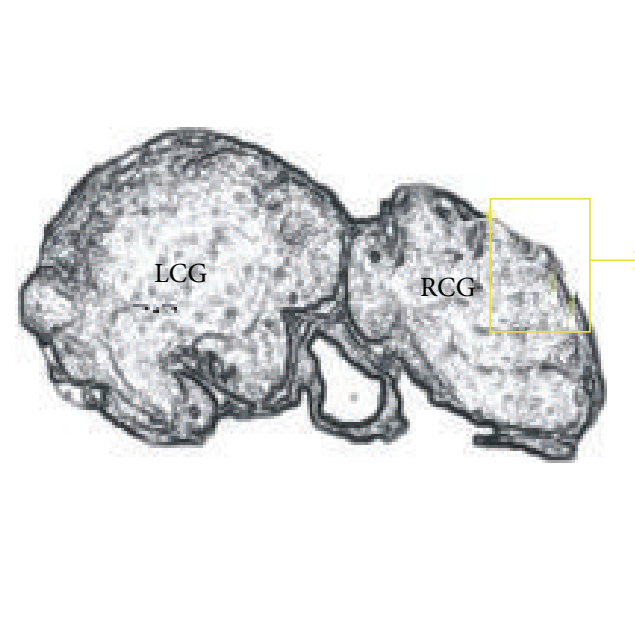

(a)

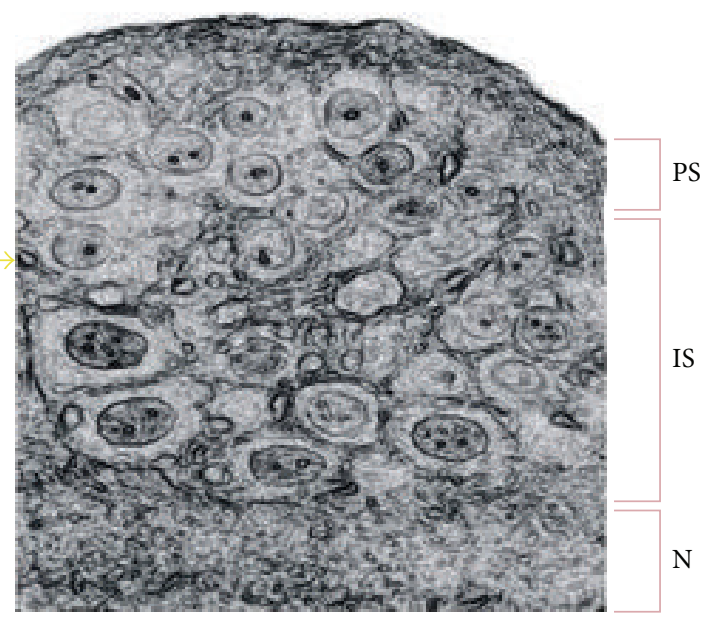

(b)

FIGURE 1: (a)-(b) ECM zones in cerebral ganglia of Bellamya bengalensis. LCG: left cerebral ganglia; RCG: right cerebral ganglia; PS: periganglionic connective tissue sheath; IS: interperikaryonal space; N: neuropil.

TABLE 1: Morphometrical data of ECM zones in CNS of S. maculata, Bellamya bengalensis, and L. corrianus. CG: cerebral ganglia, PS: periganglionic connective tissue sheath, IS: interperikaryonal space, and N: neuropil.

\begin{tabular}{lccc}
\hline & \multicolumn{2}{c}{ ECM zones in CNS of Bellamya bengalensis } \\
CG & PS (diameter in $\mu \mathrm{m})$ & IS (diameter in $\mu \mathrm{m})$ & $\mathrm{N}($ diameter in $\mu \mathrm{m})$ \\
\hline Bellamya bengalensis & $24 \pm 3$ & $58 \pm 2$ & $133 \pm 2$ \\
\hline
\end{tabular}

\subsection{Histochemical Alterations in CG after Intoxication of $\mathrm{HgCl}_{2}$ and $\mathrm{ZnCl}_{2}$}

3.1.1. Control Group. Neuronal sections fromcontrol group showed intensively magenta stained PAS positive material, that is, carbohydrates containing hexose group (Figures 2(a)$2(\mathrm{e})$ ). It included galactose and its polymers, which were distributed in the cytoplasm of neuronal cells. Histochemical results obtained by PAS reaction and $\mathrm{AB}$ showed monosaccharide, disaccharides, and other derivatives of carbohydrate with sulphated proteoglycans like heparin sulphate, chondroitin sulphate, hydectan, glypican, and syndecans, respectively; these were abundant in the sectioned neuronal cells (Figures 2(b), 2(c), 2(d), and 2(f)). Sectional view of cerebral ganglia showed presence of protein and lipid components in the cytoplasm of neuronal cells (Figures 4(a), 4(b), 5(a), 5(b), 6(a), and 6(b)).

$\mathrm{LC}_{50}$ concentration of $\mathrm{HgCl}_{2}(1.56 \mathrm{ppm})$ and $\mathrm{ZnCl}_{2}$ $(12.70 \mathrm{ppm})$ used for intoxication to the animals. Histochemical changes which occurred in the cerebral ganglia were as follows.

3.1.2. $\mathrm{HgCl}_{2}$ Treated Cerebral Neurons. $\mathrm{HgCl}_{2}$ intoxicated cerebral ganglia showed histochemical alterations after $24 \mathrm{hr}$, which included slightly decreased neutral mucins with increased acidic mucosubstances (Figures 3(a) and 3(e)). After $48 \mathrm{hrs}$, weak acidic mucosubstances as hyaluronic acid and sialomucins were stained dark blue. The carbohydrate content was reduced (Figures 3(b) and 3(f)). $72 \mathrm{hrs}$ of induction showed presence of strong and weak acidic mucosubstances with decreased glycoprotein concentration
(Figures 3(c) and 3(g)). After $96 \mathrm{hr} \mathrm{HgCl}_{2}$ exposure, acidic mucins were maximum seen in sectional view (Figure 4(h)). Protein and lipid of ECM and neuronal cells were significantly decreased after $24,48,72$, and $96 \mathrm{hr}$ of $\mathrm{HgCl}_{2}$ exposure (Figures $4(\mathrm{~b})-4(\mathrm{j})$ ).

3.1.3. $\mathrm{ZnCl}_{2}$ Treated Cerebral Neurons. After $24 \mathrm{hr}$, neurons in cerebral ganglia were moderately stained by PAS positive elements (Figures 5(a) and 5(e)). $48 \mathrm{hr}$ of exposure period showed slightly increased $\mathrm{AB}$ positive acidic contents mucosubstances as compared to $24 \mathrm{hrs}$ (Figures $5(\mathrm{~b})$ and 5(f)). Glycoprotein content from ECM of neuronal cells was more decreased after $72 \mathrm{hr}$ of exposure period, but acidic mucosubstances were increased showing strong staining intensity (Figures 5(c) and 5(g)). At $96 \mathrm{hr}$ weak and strong acids in the ECM of neuronal cells increased with declined carbohydrate content as neutral mucins (Figures 5(d) and 5(h)). Protein and lipid content of targeted cell reduced after $\mathrm{ZnCl}_{2}$ intoxication (Figures 6(b)-6(j)).

\subsubsection{Comparative Account of Histochemical Alteration in} Cerebral Ganglia of Bellamya bengalensis after Exposure to $\mathrm{HgCl}_{2}$ and $\mathrm{ZnCl}_{2}$. At comparative level, exposure to $\mathrm{HgCl}_{2}$ was found more prominent by changing histochemical contents in the cerebral ganglia of Bellamya bengalensis than to $\mathrm{ZnCl}_{2}$. After 72 and $96 \mathrm{hr}$ major decrease in PAS positive material of ECM in neurons was observed. Acidic elements like sialomucins, sulphomucins, and other weak acidic mucins were increased as per exposure period from 24 to $96 \mathrm{hr}$. The increasing order of toxicity to Bellamya 


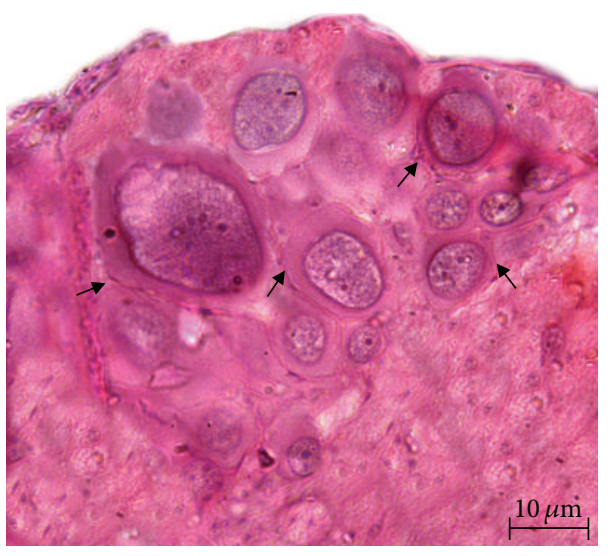

(a)

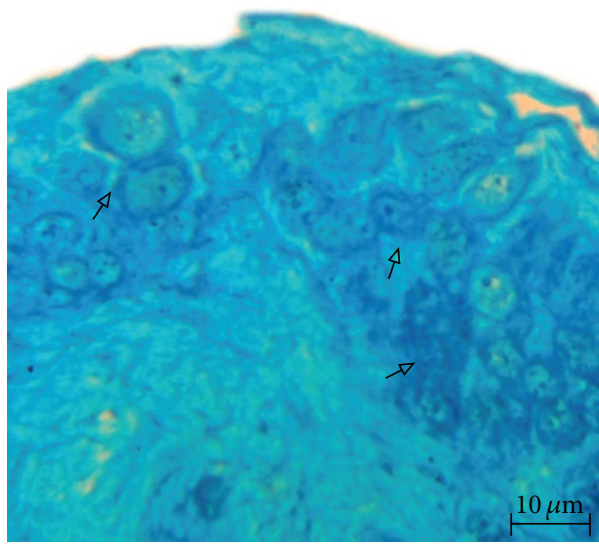

(b)

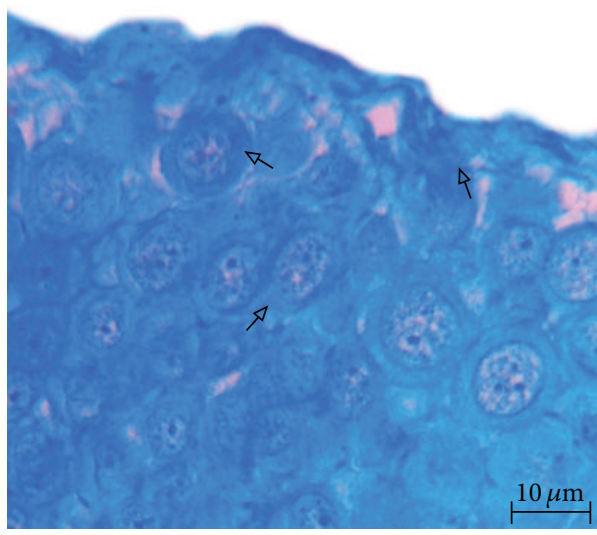

(c)

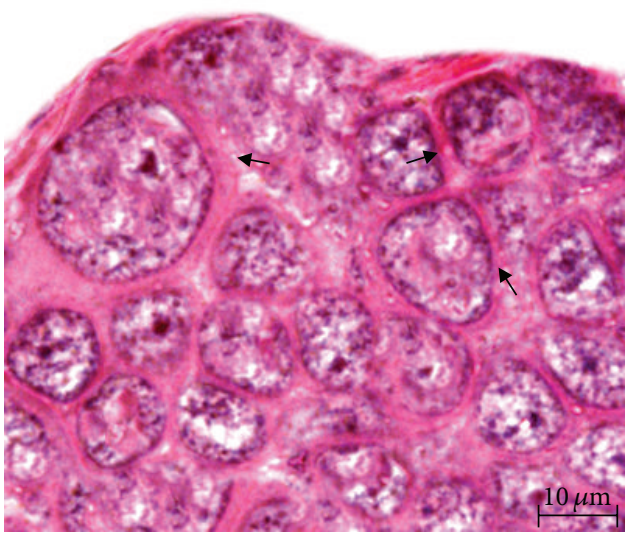

(d)

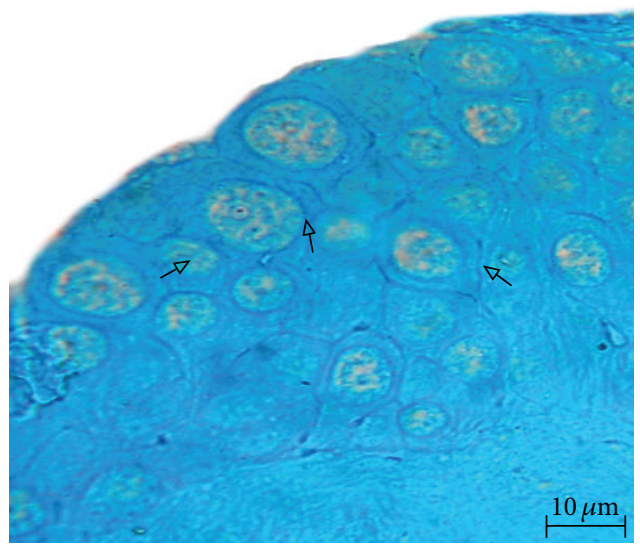

(e)

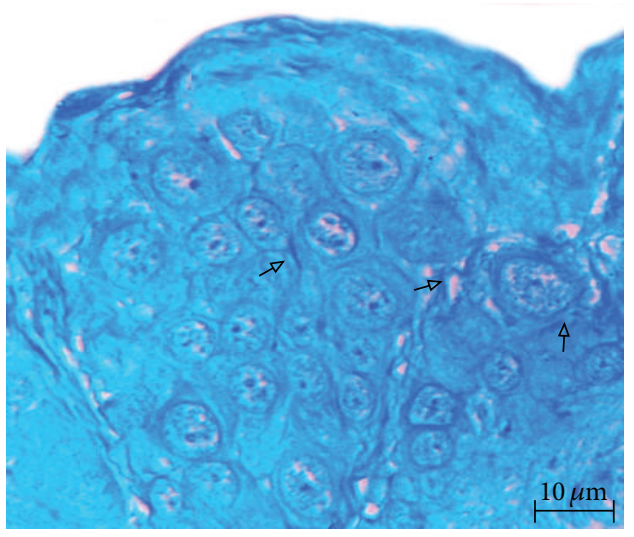

(f)

FIgURE 2: Acidic mucins in cerebral ganglia of Bellamya bengalensis from $\mathrm{HgCl}_{2}$ and $\mathrm{ZnCl}_{2}$ control group. (a)-(d) PAS: positive material in ECM of neurons. (b)-(e) AB at pH 1.0: stained acidic mucosubstances in ECM, (c)-(f) AB at pH 2.5: stained acidic mucosubstances in ECM 400x. Bold arrow indicates positive staining; hollow arrow indicates increased acid mucins.

bengalensis wasfound to be $\mathrm{Hg}>\mathrm{Zn}>\mathrm{Co}$. The comparative account of staining intensity score is noted in Table 2 .

\section{Discussion}

Histochemically, a cerebral ganglion of snail Bellamya bengalensis has three different mucins zones, namely, periganglionic connective tissue sheath, interperikaryonal space, and neuropil. Similar results are reported in [23] about the cerebral ganglia of the Helix pomatia. Reference [24] has recorded that PS has an important role in water retention, regulation, and transportation mechanism, as per the different habitat (terrestrial and aquatic), and so histochemical components of ECM of CNS have marked role in maintaining the homeostasis of neuronal secretion and activity related to 


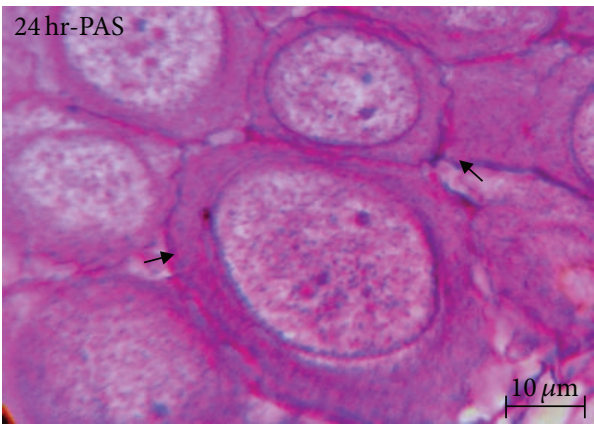

(a)

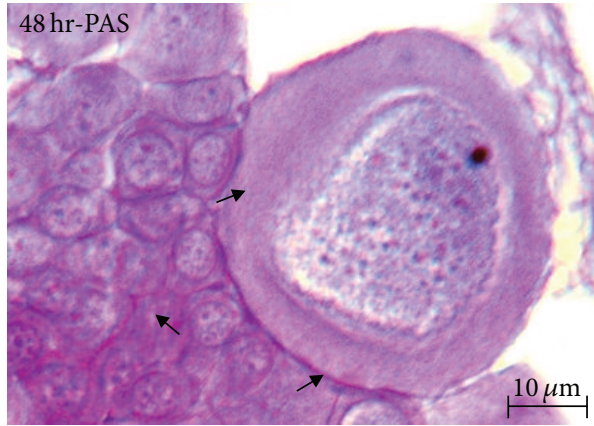

(b)

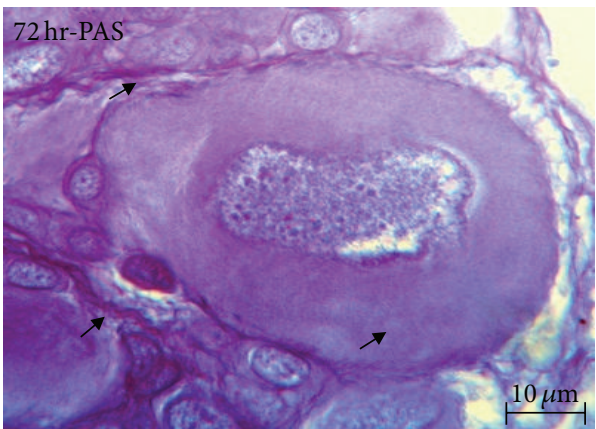

(c)

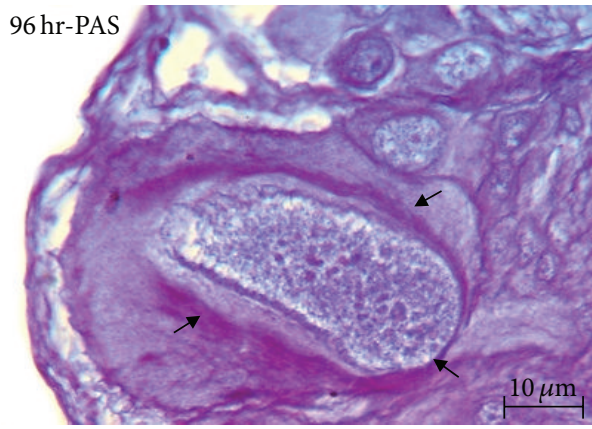

(d)

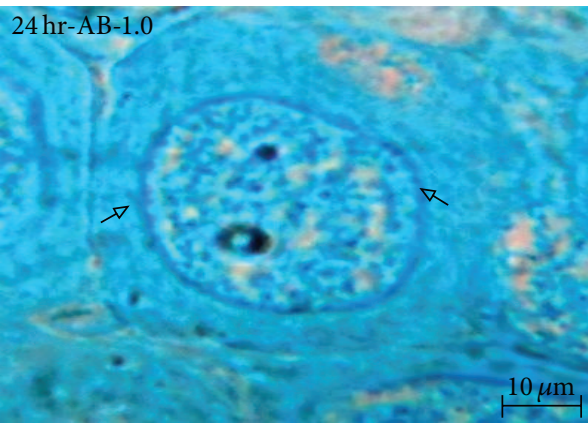

(e)

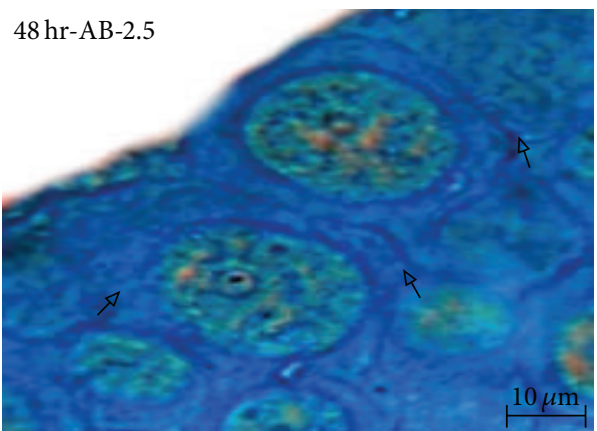

(f)

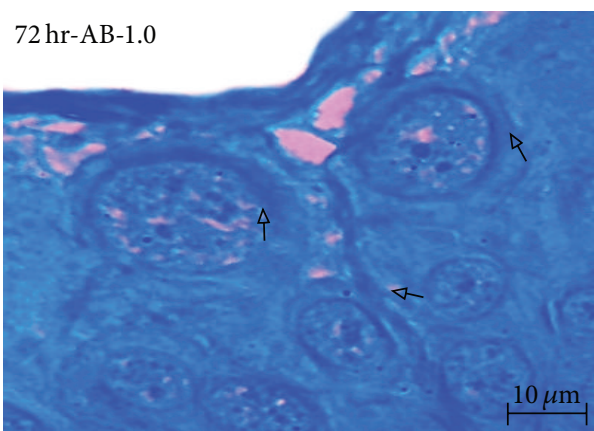

(g)

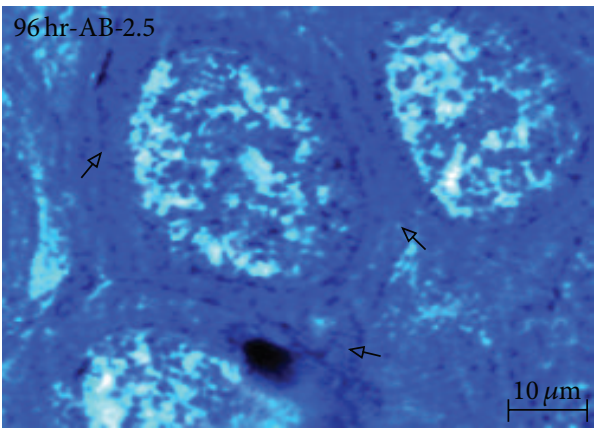

(h)

FIGURE 3: $\mathrm{HgCl}_{2}$ induced histochemical alterations in cerebral ganglia of snail Bellamya bengalensis at different exposure periods. (a)-(d) Reduced glycogen content in cerebral ganglia; (e)-(h) AB at $\mathrm{pH}$ 1.0, 2.5 showed increased strong and weak acid mucins in cerebral ganglia; (a), (e) $24 \mathrm{hr} \mathrm{1000x;} \mathrm{(b),} \mathrm{(f)} 48 \mathrm{hr} \mathrm{1000x;} \mathrm{(c),} \mathrm{(g)} 72 \mathrm{hr} \mathrm{1000x;} \mathrm{(d),} \mathrm{(h)} 96 \mathrm{hr} \mathrm{1000x.} \mathrm{Bold} \mathrm{arrow} \mathrm{indicates} \mathrm{decreased} \mathrm{carbohydrate;} \mathrm{hollow} \mathrm{arrow}$ indicates increased acid mucins. 


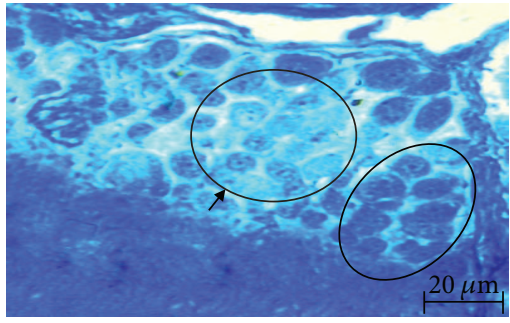

(a)

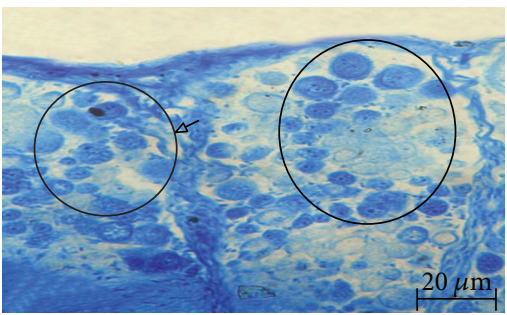

(b)

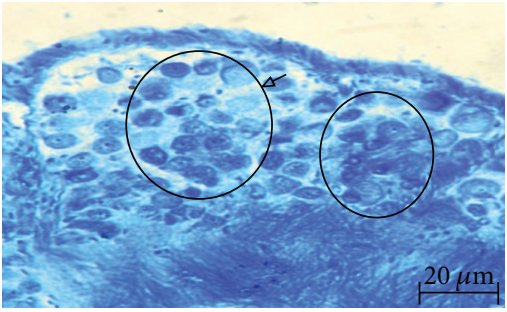

(c)

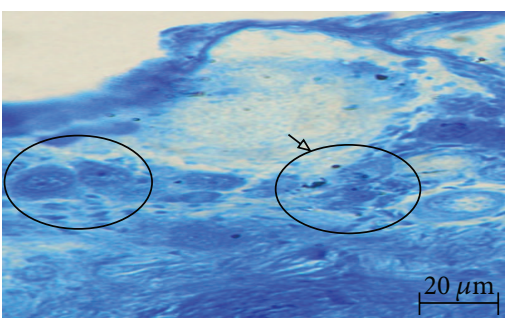

(d)

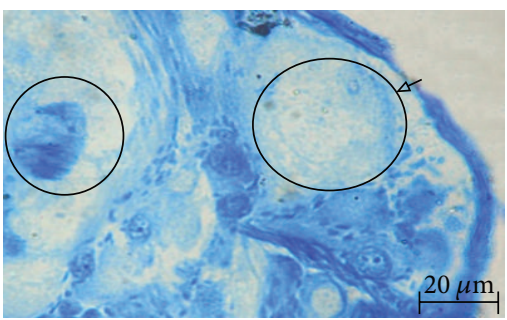

(e)

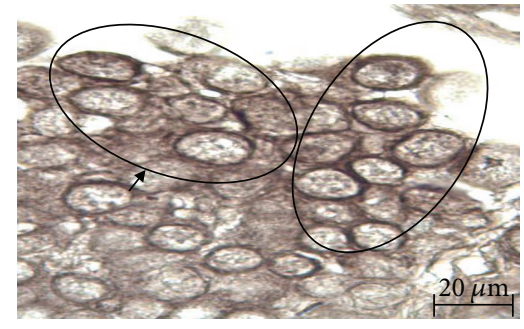

(f)

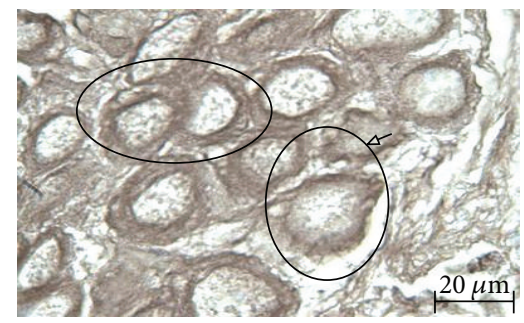

(g)

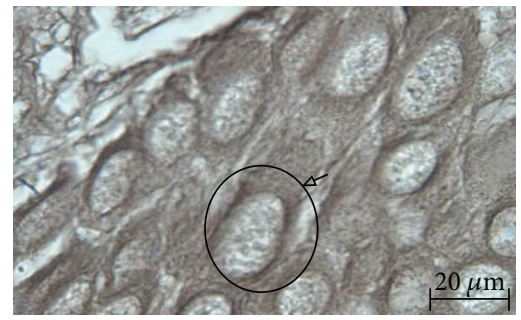

(h)

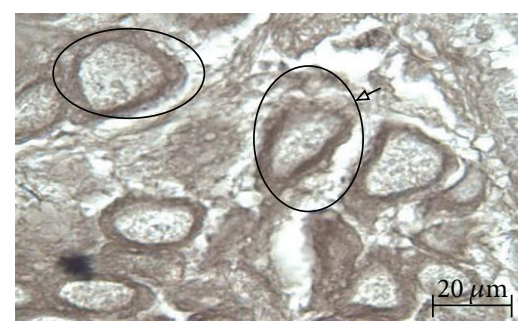

(i)

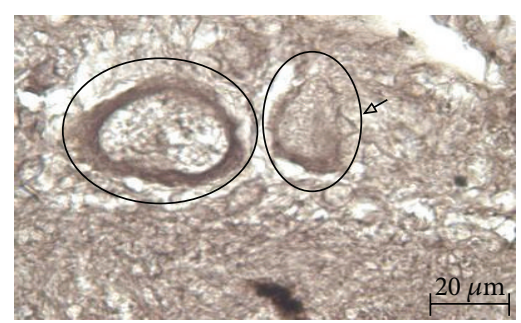

(j)

Figure 4: Protein and lipid content in cerebral ganglia of Bellamya bengalensis after $\mathrm{HgCl}_{2}$ intoxication. (b)-(e) Mercury bromophenol blue stained reduced proteins in cerebral ganglia; (g)-(j) Sudan black B stained depleted lipids content in cerebral ganglia; (a), (f) control group 400x; (b), (g) 24 hr 400x; (c), (h) 48 hr 400x; (d), (i) 72 hr 400x; (e), (j) 96 hr 400x. Bold arrow indicates presence of protein and lipid; hollow arrow indicates decreased protein and lipid. 


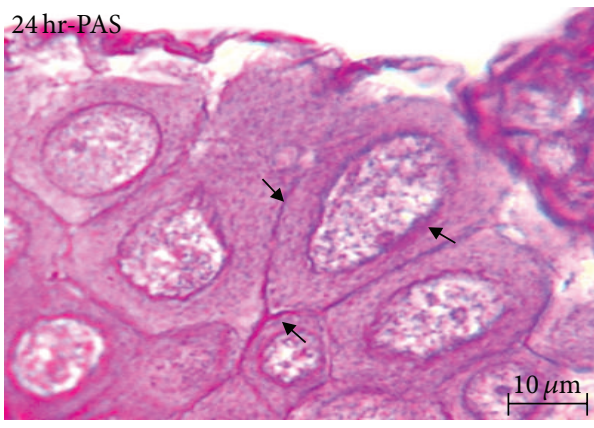

(a)

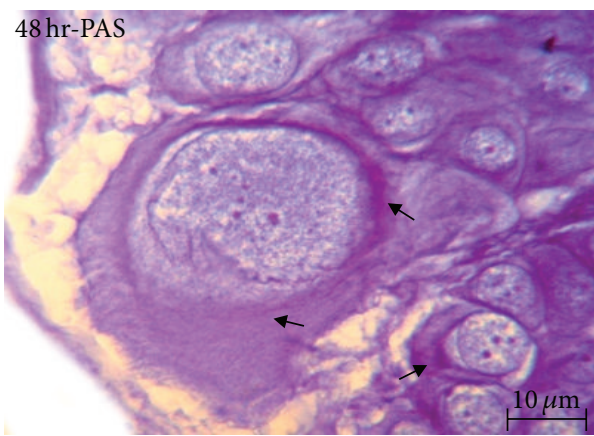

(b)

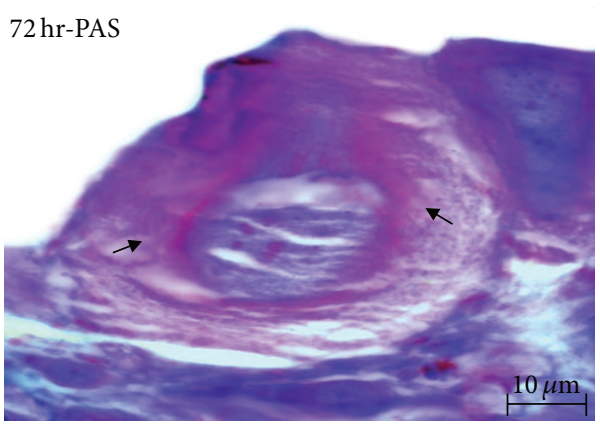

(c)

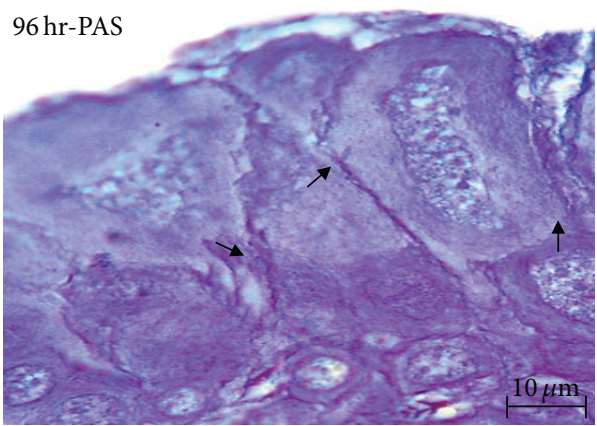

(d)

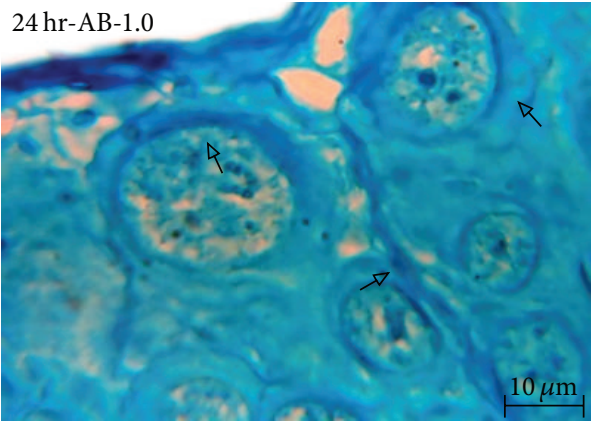

(e)

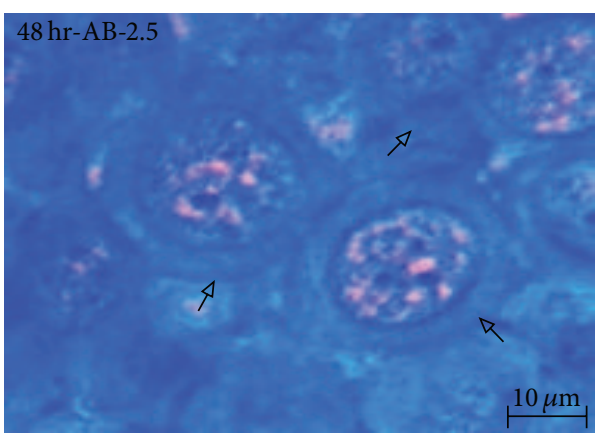

(f)

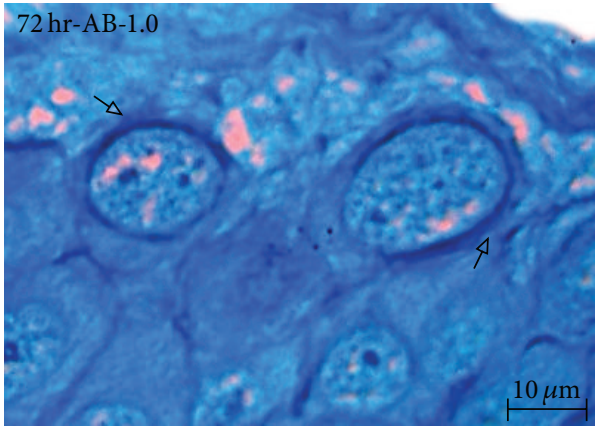

(g)

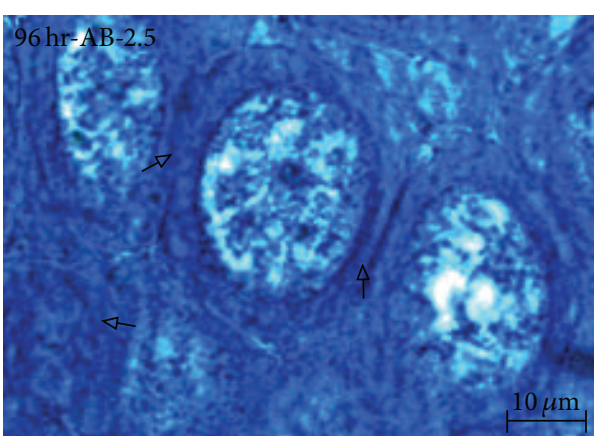

(h)

FIGURE 5: Neural and acid mucosubstances in cerebral ganglia of Bellamya bengalensis from $\mathrm{ZnCl}_{2}$ control group. (a) PAS: positive material in ECM of neurons, 1000x; (b)-(c) AB at pH 1.0, 2.5: stained acidic mucosubstances in ECM of neurons, 1000x. Bold arrow indicates positive staining; hollow arrow indicates increased acid mucins. 


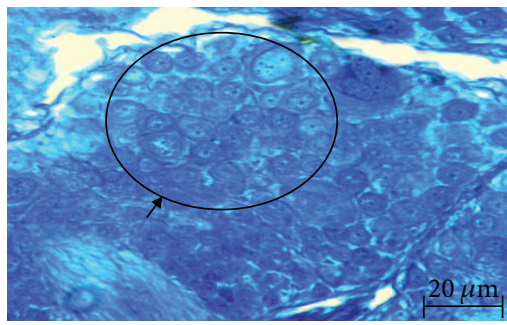

(a)

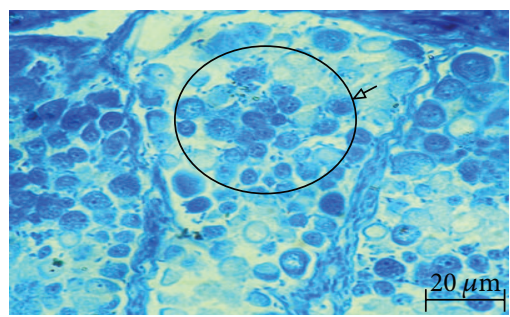

(b)

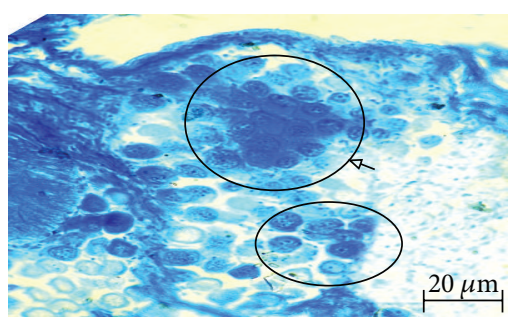

(c)

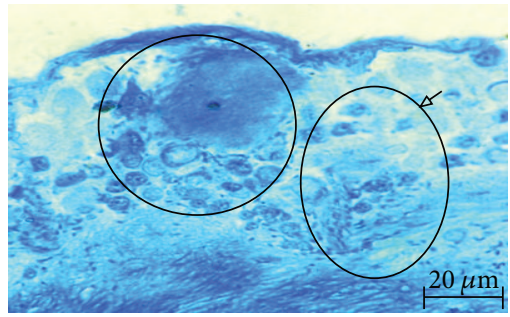

(d)

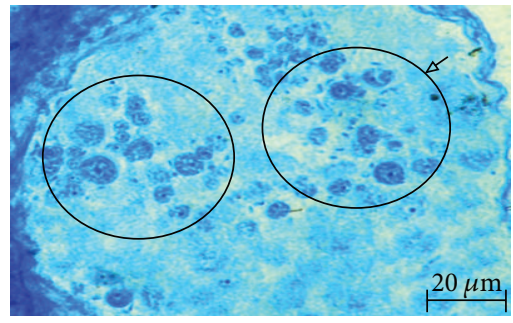

(e)

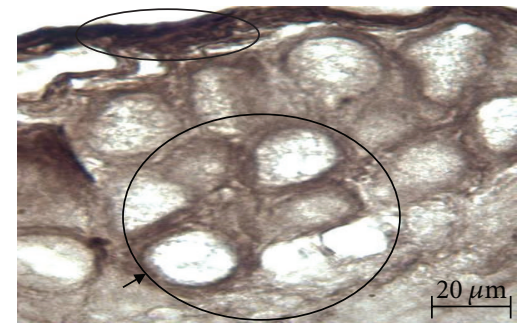

(f)

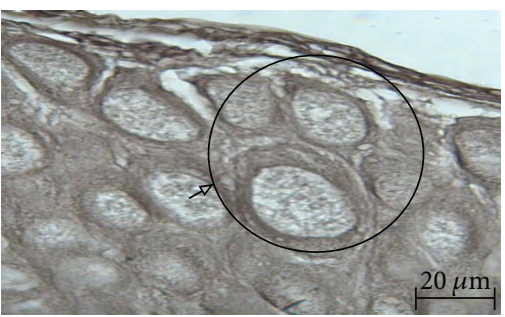

(g)

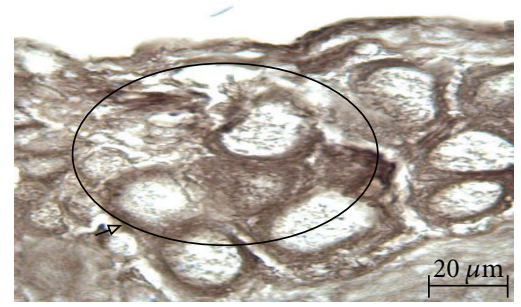

(h)

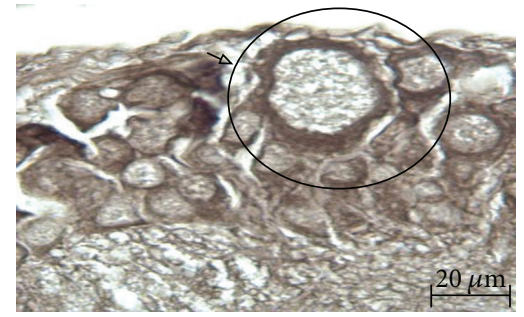

(i)

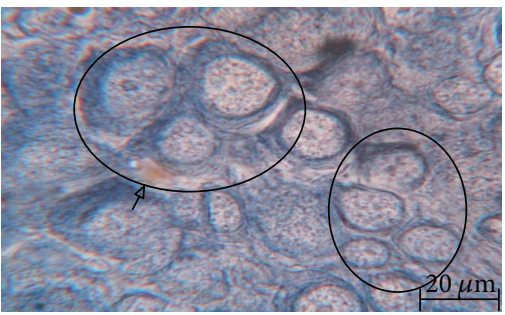

(j)

FIGURE 6: Protein and lipid content in cerebral ganglia of $S$. maculata after $\mathrm{ZnCl}_{2}$ intoxication. (b)-(e) Mercury bromophenol blue stained proteins in cerebral ganglia; (g)-(j) Sudan black B stained lipids in cerebral ganglia; (a), (f) control group 400x; (b), (g) 24 hr 400x; (c), (h) $48 \mathrm{hr} 400 \mathrm{x}$; (d), (i) $72 \mathrm{hr} 400 \mathrm{x}$; (e), (j) $96 \mathrm{hr} 400 \mathrm{x}$. Bold arrow indicates presence of protein and lipid; hollow arrow indicates decreased protein and lipid. 
TABLE 2: Staining intensity of glycoconjugate in ECM of neuronal cells in control and intoxicated snail B. bengalensis. AB: alcian blue, PAS: periodic acid, +: moderate reaction, ++: strong reaction, +++: very strong reaction, T: turquoise, and M: magenta.

\begin{tabular}{|c|c|c|c|c|c|c|}
\hline \multirow{2}{*}{ Heavy metals } & \multirow{2}{*}{ Procedure } & \multicolumn{5}{|c|}{ Staining intensity } \\
\hline & & Control & $24 \mathrm{hr}$ & $48 \mathrm{hr}$ & $72 \mathrm{hr}$ & $96 \mathrm{hr}$ \\
\hline \multirow{5}{*}{$\mathrm{HgCl}_{2}$ induction } & $\mathrm{AB} \mathrm{pH}-1.0$ & $+\mathrm{T}$ & $++\mathrm{T}$ & $++\mathrm{T}$ & $+++\mathrm{T}$ & $+++\mathrm{T}$ \\
\hline & $\mathrm{AB} \mathrm{pH}-2.5$ & $+\mathrm{T}$ & $++\mathrm{T}$ & $+++\mathrm{T}$ & $+++\mathrm{T}$ & $+++\mathrm{T}$ \\
\hline & PAS & $+++\mathrm{M}$ & $++\mathrm{M}$ & $+\mathrm{M}$ & $+\mathrm{M}$ & $+\mathrm{M}$ \\
\hline & $\mathrm{MBB}$ & +++ & ++ & + & + & + \\
\hline & SBB & +++ & ++ & + & + & + \\
\hline \multirow{5}{*}{$\mathrm{ZnCl}_{2}$ induction } & $\mathrm{AB} p \mathrm{H}-1.0$ & $+\mathrm{T}$ & $+\mathrm{T}$ & $++\mathrm{T}$ & $++\mathrm{T}$ & $+++\mathrm{T}$ \\
\hline & $\mathrm{AB} \mathrm{pH}-2.5$ & $+\mathrm{T}$ & $+\mathrm{T}$ & $++\mathrm{T}$ & $+++\mathrm{T}$ & $+++\mathrm{T}$ \\
\hline & PAS & $+++\mathrm{M}$ & $+++\mathrm{M}$ & $++\mathrm{M}$ & $+\mathrm{M}$ & $+\mathrm{M}$ \\
\hline & $\mathrm{MBB}$ & +++ & +++ & ++ & ++ & + \\
\hline & SBB & +++ & +++ & ++ & ++ & ++ \\
\hline
\end{tabular}

sudden changes in humidity and temperature. Reference [25] reported that chemical content of the neuronal cells played crucial role in the movement, guidance, and synaptic formation of neurons during developments which also determines the regeneration potential of neurons in the adult nervous tissue after the injury.

In the present investigation, histochemical results showed different monosaccharides, disaccharides, and other derivatives of carbohydrate and sulphated proteoglycans like heparin sulphate, chondroitin sulphate, hydectan, glypican, and syndecans, respectively; proteins and lipids were observed in major concentration in the ECM of cerebral neurons in snail Bellamya bengalensis. Histochemically, [26] documented carbohydrates as large molecules on the outside surface of all types of cell with its secretion and stored within cell and ECM. Alcian blue at pH 2.5 labeled most of the acidic sulphated groups which contained proteoglycans in CNS of Lymnaea stagnalis and Helix pomatia documented by [24]. Reference [27] reported concentration of neutral and acidic mucosubstances in the ECM of neurons from three different zones in Semperula maculata. In the present investigation we observed concentration of protein and lipid molecules in the neuronal cell and ECM of cerebral ganglia of all the experimental molluscan species. Reference [28] noted responsibility of protein macromolecules for the mechanical integrity of the ganglia. Whereas storage function of proteoglycans and predominantly negative charged sulphated proteoglycans for water and ionic salts, which provide significant polarity to the ECM.

After intoxication of $\mathrm{HgCl}_{2}$ and $\mathrm{ZnCl}_{2}$, glycoconjugates from different areas of neuronal cells were found declined as per increased time of exposure. The results obtained in the present study showed that the neutral mucins as polysaccharides and mucosaccharides containing hexose or deoxyhexoses with vic-glycol groups were decreased significantly against sublethal concentrations of $\mathrm{HgCl}_{2}$ and $\mathrm{ZnCl}_{2}$. Similarly scientist noted decreased concentration of neutral mucosubstances with elevated concentration of acidic content due to metal toxicity in the cells and glands of many organs of invertebrate animals [29]. The depletion of glycogen content may be due to its rapid utilization in the metabolic reaction to meet the energy demands under the impact of heavy metal toxicity.

Reduced concentration of neutral mucopolysaccharide in the ECM of neuronal cells indicated the active glycogenolysis in the tissues. Tissue acidosis due to reduced oxygen transport must have also favored the process of glycogenolysis. Likewise, in present study, the acidic mucopolysaccharide as chondroitin, chondroitin sulphate, kerato sulphate, hyaluronic acid, heparin, and heparin sulphate was significantly increased due to exposure to $\mathrm{HgCl}_{2}$ and $\mathrm{ZnCl}_{2}$. Authors in [30] observed histochemical changes in digestive gland of Homarus americanus where they documented increased concentration of acidic mucosubstances in tissues/cells of experimental animal. Decreased glycogen content in various organisms after exposure to the pollutant was well documented in [31]. Reference [32] documented toxicity of $\mathrm{HgCl}_{2}$ and $\mathrm{CdCl}_{2}$, where the neutral mucins decreased with increased acidic mucosubstances in the ECM of cerebral neurons in terrestrial slug Semperula maculata. Protein and lipid content from the cerebral ganglia was decreased after $96 \mathrm{hr}$ of exposure to $\mathrm{HgCl}_{2}$ and $\mathrm{ZnCl}_{2}$. Reference [33] similarly documented that heavy metal toxicity minimized the concentration of the neutral mucosubstances, protein, and lipid in the hepatopancreas of the Barytelphusa guerini.

In conclusion, $\mathrm{HgCl}_{2}$ and $\mathrm{ZnCl}_{2}$ have altered histochemical content of neuronal cells of freshwater snail Bellamya bengalensis. Carbohydrate, protein, and lipid are the primary sources of energy; in intoxication as per exposure period these elements were highly utilized by experimental animal against the toxic stress of heavy metals. In toxicity point of view $\mathrm{HgCl}_{2}$ was found more toxic than $\mathrm{ZnCl}_{2}$.

\section{Conflict of Interests}

The authors declare that there is no conflict of interests regarding the publication of this paper.

\section{Acknowledgments}

The authors are thankful to DST-PURSE, New Delhi, for providing financial support under scheme. The authors are 
also thankful to the Head of Department of Zoology, Shivaji University, Kolhapur, for providing facilities in the progress of work.

\section{References}

[1] J. Khayatzadeh and E. Abbasi, "The effects of heavy metals on aquatic animals," in Proceedings of the 1st International Applied Geological Congress, pp. 26-28, Department of Geology, Islamic Azad University, Mashhad, Iran, April 2010.

[2] M. Ghosh and S. P. Singh, "A review on phytoremediation of heavy metals and utilization of its byproducts," Applied Ecology and Environmental Research, vol. 3, no. 1, pp. 1-18, 2005.

[3] J. P. Jadhav, D. C. Kalyani, A. A. Telke, S. S. Phugare, and S. P. Govindwar, "Evaluation of the efficacy of a bacterial consortium for the removal of color, reduction of heavy metals, and toxicity from textile dye effluent," Bioresource Technology, vol. 101, no. 1, pp. 165-173, 2010.

[4] H. Yang and N. Rose, "Trace element pollution records in some UK lake sediments, their history, influence factors and regional differences," Environment International, vol. 31, no. 1, pp. 63-75, 2005.

[5] G. W. Bryan and W. J. Langston, "Bioavailability, accumulation and effects of heavy metals in sediments with special reference to United Kingdom estuaries," Environmental Pollution, vol. 76, no. 2, pp. 89-131, 1992.

[6] M. B. Mule and V. S. Lomte, "Effect of heavy metals $\left(\mathrm{CuSo}_{4}\right.$ and $\mathrm{HgCl}_{2}$ ) on the oxygen consumption of the freshwater snail, Thiara tuberculata," Journal of Environmental Biology, vol. 15, no. 4, pp. 263-268, 1994.

[7] A. A. Otitoloju and K. N. Don-Pedro, "Integrated laboratory and field assessments of heavy metals accumulation in edible periwinkle, Tympanotonus fuscatus var radula (L.)," Ecotoxicology and Environmental Safety, vol. 57, no. 3, pp. 354-362, 2004.

[8] T. I. Balkas, S. Tugrul, and I. Salihoglu, "Trace metal levels in fish and crustacea from northeastern Mediterranean coastal waters," Marine Environmental Research, vol. 6, no. 4, pp. 281-289, 1982.

[9] S. I. Dodson, Introduction to Limnology, McGraw-Hill, New York, NY, USA, 2005.

[10] J. L. Farris and J. H. van Hassel, Freshwater Bivalve Ecotoxicology, CRC Press, Boca Raton, Fla, USA, 2007.

[11] M. Pietrock, T. Meinelt, and D. J. Marcogliese, "Effects of cadmium exposure on embryogenesis of Stagnicola elodes (Mollusca, Gastropoda): potential consequences for parasite transmission," Archives of Environmental Contamination and Toxicology, vol. 55, no. 1, pp. 43-48, 2008.

[12] L. K. Russell, J. I. DeHaven, and R. P. Botts, "Toxic effects of cadmium on the garden snail (Helix aspersa)," Bulletin of Environmental Contamination and Toxicology, vol. 26, no. 5, pp. 634-640, 1981.

[13] A. T. AbdAllah and M. A. Moustafa, "Accumulation of lead and cadmium in the marine prosobranch Nerita saxtilis, chemical analysis, light and electron microscopy," Environmental Pollution, vol. 116, no. 2, pp. 185-191, 2002.

[14] M. Presing, V. K. Balogh, and J. Salanki, "Cadmium uptake and depuration in different organs of Lymnaea stagnalis L. and the effect of cadmium on the natural zinc level," Archives of Environmental Contamination and Toxicology, vol. 24, no. 1, pp. 28-34, 1993.
[15] H. J. Herwig, F. Brands, E. Kruitwagen, and D. I. Zandee, "Bioaccumulation and histochemical localization of cadmium in Dreissena polymorpha exposed to cadmium chloride," Aquatic Toxicology, vol. 15, no. 3, pp. 269-285, 1989.

[16] P. Tanhan, P. Sretarugsa, P. Pokethitiyook, M. Kruatrachue, and E. S. Upatham, "Histopathological alterations in the edible snail, Babylonia areolata (spotted babylon), in acute and subchronic cadmium poisoning," Environmental Toxicology, vol. 20, no. 2, pp. 142-149, 2005.

[17] A. A. Otitoloju, D. O. Ajikobi, and R. I. Egonmwan, "Histopathology and bioaccumulation of heavy metals $(\mathrm{Cu}$ and $\mathrm{Pb})$ in the giant land snail, Archachatina marginata (Swainson)," The Open Environmental Pollution and Toxicological Journal, vol. 1, pp. 79-88, 2009.

[18] R. D. Hawkins, E. R. Kandel, and C. H. Bailey, "Molecular mechanisms of memory storage in Aplysia," Biological Bulletin, vol. 210, no. 3, pp. 174-191, 2006.

[19] J. F. A. McManus, "Histological demonstration of mucin after periodic acid," Nature, vol. 158, no. 4006, p. 202, 1946.

[20] S. S. Spicer, "A correlative study of the histochemical properties of rodent acid mucopolysaccharides," Journal of Histochemistry and Cytochemistry, vol. 8, pp. 18-35, 1960.

[21] D. M. Chapman, "Dichromatism of bromphenol blue, with an improvement in the mercuric bromphenol blue technic for protein," Stain Technology, vol. 50, no. 1, pp. 25-30, 1975.

[22] T. L. Chiffelle and F. A. Putt, "Propylene and ethylene glycol as solvents for Sudan IV and Sudan black B," Stain Technology, vol. 26, no. 1, pp. 51-56, 1951.

[23] Z. Sefozo and K. Elekes, "Chemical properties of the extracellular matrix of the snail nervous system: a comprehensive study using a combination of histochemical techniques," Micron, vol. 41, no. 5, pp. 461-471, 2010.

[24] Z. Serfozo and K. Elekes, "Histochemistry of the extracellular matrix in the snail central nervous system," Ideggyógyászati Szemle, vol. 60, no. 3-4, pp. 173-176, 2007.

[25] U. Hartmann and P. Maurer, "Proteoglycans in the nervous system - the quest for functional roles in vivo," Matrix Biology, vol. 20, no. 1, pp. 23-35, 2001.

[26] J. A. Kieman, "Carbohydrate histochemistry," Technical Article, pp. 68-78, 2010.

[27] N. A. Kamble and S. R. Londhe, "Neurohistochemistry in molluscan species: focus on extracellular matrix," Invertebrate Neuroscience, vol. 12, no. 2, pp. 129-138, 2012.

[28] E. Syková, "Extrasynaptic volume transmission and diffusion parameters of the extracellular space," Neuroscience, vol. 129, no. 4, pp. 861-876, 2004.

[29] S. Valarmathi, Environmental quality of coastal zone of Madras and impact of pollutants on Sesarma quadrtum (Fbricus) [Ph.D. thesis], University of Madras, Tamilnadu, India, 2000.

[30] F. P. Thurberg, A. Calabrace, and M. A. Dawso, "Effect of silver on oxygen consumption of bivalves at various salinities, in pollution and physiology of marine organisms," in Pollution and Physiology of Marine Organisms, F. J. Vernberg and W. B. Vernberg, Eds., p. 67, Academic Press, New York, NY, USA, 1974.

[31] T. S. Gill and J. C. Pant, "Effects of sublethal concentrations of mercury in a teleost Puntius conchonius: biochemical \& haematological responses," Indian Journal of Experimental Biology, vol. 19 , no. 6, pp. 571-573, 1981. 
[32] N. A. Kamble and S. R. Londhe, "Epileptic activity in neuronal cells, induced by mercuric chloride and cadmium chloride in terrestrial slug Semperula maculata: fine structure investigated by histology and histochemistry," Toxicological and Environmental Chemistry, vol. 94, no. 1, pp. 109-120, 2012.

[33] R. Nagabhushanam, G. Gyananath, and R. Sarojini, “Toxicity of three organophosphate compounds and their effect on the gonad of freshwater prawn, Macrobrachium lamerri," Indian Journal of Comparative Animal Physiology, vol. 1, p. 13, 1983. 

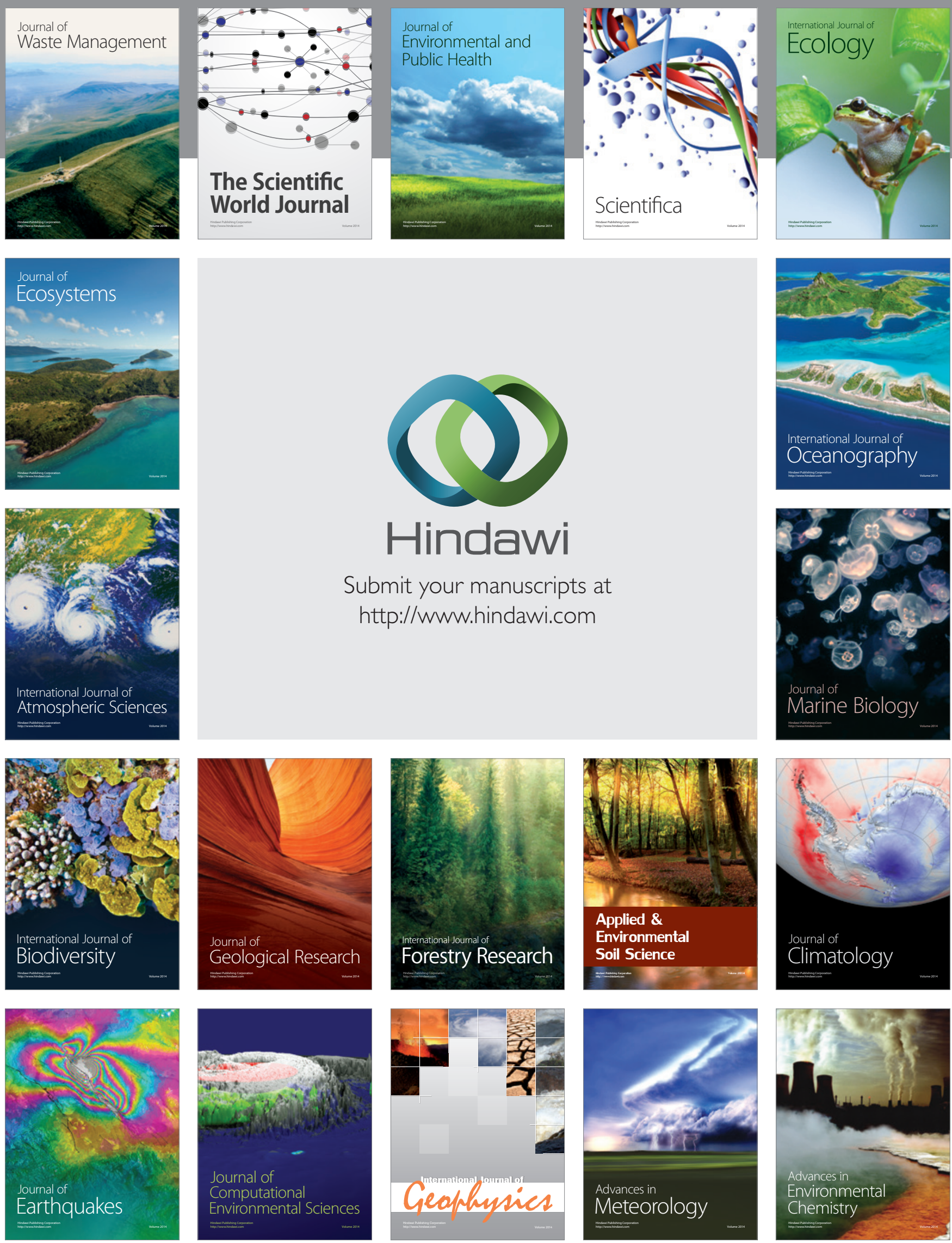